\title{
Аналіз проблем професійної підготовки громадян України за програмою підготовки офіцерів запасу
}

\author{
Максим Кас'яненко * А \\ А Департаменту військової освіти і науки Міністерства оборони України, пр-кт Повітрофлотський, 28, м. Київ, 03049, Україна
}

Received: October 18, 2020 | Revised: October 27, 2020 | Accepted: October 31, 2020

DOI: $10.33445 /$ sds.2020.10.5.15

\begin{abstract}
Анотація
Стаття присвячена аналізу стану підготовки майбутніх офіцерів запасу. Події на Сході України розкрили цілу низку проблем у системі підготовки офіцерів запасу. За результатами аналізу наукових праць встановлено, що у процесі військової підготовки громадян України за програмою підготовки офіцерів запасу не враховуються такі чинники, як зміна способу комплектування військових формувань, впровадження стандартів країн НАТО у військовій сфері, досвід бойових дій на Сході України. У статті визначено особливості та запропоновано шляхи вдосконалення системи підготовки офіцерів запасу. Мета стапті $\epsilon$ аналіз основних проблеми професійної підготовки громадян України за програмою підготовки офіцерів запасу та розглянути шляхи подальшого удосконалення системи підготовки офіцерів запасу, як одного з видів військового обов'язку.
\end{abstract}

Ключові слова: військова підготовка, офіцери запасу, військово-професійна діяльність, система професійної підготовки, професійна готовність.

\section{Постановка проблеми}

Основним показником обороноздатності країни та ефективності державного управління у військовій сфері $\epsilon$ спроможність особового складу Збройних Сил України виконувати покладені на нього завдання по захисту цілісності та недоторканості нашої держави (ст. 17 Конституції України). Але початок окупації АР Крим та агресії Російської Федерації на сході України в 2014 році, провальні військові операції: Ізваренський котел (загиблих 125, поранених 706, полон більше 500 військовослужбовців, знищено 144 БМП, 26 танків, 19 самохідних артилерійських установок типу 2C1 “Гвоздика", 2C5 “Гіацинт-С”, 2C3 "Акація", 10 реактивних систем залпового вогню, 17 гаубиць Д-30., в ході битви на кордоні офіційно підтверджені втрати авіації Сил АТО становлять 3 Су-25, 1 Ан-26, 1 гелікоптер Мі-8), Іловайський (230 загиблих, 270 поранених), Дебальцево (більше 250 загиблих та 330 поранених, знищено 46 танків, 94 БМП, 10 БРМ$1 \mathrm{~K}, 29$ БТР, 16 САУ, 6 гаубиць и 14 протитанкових гармат) [1], комплектування військових частин мобілізованими, які погано підготовлені, взагалі професійна неготовність командування всіх рівнів до ведення повномасштабної війни на території України. У цих умовах актуалізується проблема якості підготовки майбутніх офіцерів запасу.

3 оголошенням часткової мобілізації, держава Україна зіткнулася з таким явищем: 3 одного боку - високий патріотичний та морально-психологічний підйом і готовність громадян стати на захист Батьківщини, а 3 іншого - низький військовий вишкіл, особливо тих, хто не проходив військової служби. Томуна бойове злагодження військових підрозділів (батальйонів) витрачається, в окремих випадках, до двох місяців замість одного-двох тижнів. Ще одна проблема полягає в тому, що відсоток студентів, які бажають пов'язати своє життя в мирний час зі службою в ЗС України після закінчення навчання у закладах вищої освіти, дуже низький. Мотивація більшості 3

\footnotetext{
* к.в.н., заступник директора департаменту - начальник відділу, e-mail: zdd_dvon@mil.gov.ua, ORCID: 0000-0002-3749-4441
} 
них - отримання первинного офіцерського звання “молодший лейтенант запасу”, щоб не бути призваним на строкову службу або бути прийнятим на службу в інші силові структури, деякі з них хочуть мати переваги на посадах державної служби [2].

Непрості завдання, які стоять сьогодні перед Збройними Силами України, різко підняли планку відповідності їм людей в погонах. Гібридна війна, нові форми і способи військових дій, сучасні озброєння і військова техніка, інформатизація та впровадження в сферу збройної боротьби інноваційних технологій зажадали серйозно підвищити рівень професійної підготовки офіцерів та солдатів [3].
Тому, виникає необхідність проаналізувати проблеми професійної підготовки громадян України за програмою офіцерів запасу. У сучасних умовах особливої актуальності набула проблема якості підготовки майбутніх офіцерів запасу. Події на Сході України яскраво свідчать про наявність принципових розбіжностей між потребами та традиційним змістом і методами підготовки резерву для військових формувань. Наявні підходи до організації освітнього процесу офіцерів запасу виявились не досить ефективними. у результаті за наявності достатнього за чисельністю резерву у державі відчувається дефіцит кваліфікованих кадрів 3 числа офіцерів запасу [4].

\section{Аналіз останніх досліджень та публікацій}

Окремі складові професійної підготовки офіцерів вивчали такі науковці, як М. Банько, В. Гриньков, І. Грязнов, А. Деркач, А. Зельницький, В. Клачко, С. Козін, В. Кортенко, С. Кубіцький, А. Лігоцький, Ю. Приходько, І. Радванський, В. Райко, Л. Рудкевич, А. Руднєвська, І. Руснак, Ю. Сердюк, А. Сіцінський, Т. Ткаченко, В. Телелим, О. Торічний, М. Худякова, Г. Яворська, В. Ягупов. Проблемою удосконалення професійної підготовки громадян України за програмою підготовки офіцерів запасу займались і займаються такі учені, як В. Баришніков та О.
Неймирок, О. Безносюк, Є. Брижатий, А. Дерев'янчук, проблемою формування готовності майбутніх офіцерів до професійної діяльності: А. Балендр, О. Богданюк, С. Кубіцький, Л. Матохнюк, І. Платонов, А. Сіцінський, О. Старчук, В. Уліч, Проблеми, що пов'язані з практикою професійної підготовки офіцерів запасу, розглядали О. Аршинов, О. Безносюк, В. Євстаф'єв, Г. Кабакович, Ю. Кудрявцев, М. Науменко, М. Нещадим, $€$. Подтергера, В. Ройлян, С. Сінкевич, М. Соловцов, Ю. Тарський, С. Фільков, І. Хорєв, В. Чабаненко та ін.

\section{Постановка завдання}

У сучасних умовах особливої актуальності набула проблема якості підготовки майбутніх офіцерів запасу. 3 огляду на складні реалії сьогодення метою статті $\epsilon$ аналіз основних проблем професійної підготовки громадян України за програмою підготовки офіцерів запасу, запропонувати шляхи подальшого удосконалення системи підготовки офіцерів запасу, як одного з видів військового обов'язку. Так, як наявні підходи до організації освітнього процесу офіцерів запасу виявились не досить ефективними.

\section{Виклад основного матеріалу}

Події на Сході України розкрили цілу низку проблем в системі підготовки офіцерських кадрів, у тому числі i офіцерів, які призиваються із запасу [5].

В Україні система підготовки офіцерів запасу створена для забезпечення З У України та інших військових формувань необхідною кількістю підготовлених громадян для виконання військового обов'язку в запасі, проходження служби у військовому резерві зС України та інших військових формувань, а також для забезпечення реалізації права громадян на рівні можливості у виборі професії шляхом здобуття додаткових знань, 
умінь і навичок, необхідних для належного виконання військового обов'язку в запасі у мирний час, військової служби у воєнний час та для майбутньої професійної діяльності [3].

Військову підготовку за програмою підготовки офіцерів запасу на добровільних засадах проходять громадяни України, які мають або здобувають освітній ступінь вищої освіти не нижче бакалавра, придатні до військової служби за станом здоров'я та морально-діловими якостями.

Громадяни України можуть проходити військову підготовку за умови відповідності напряму їх підготовки у закладах вищої освіти (ЗВО) військово-обліковій спеціальності (BOC), за якою проводиться підготовка офіцерів запасу [6].

Військова підготовка включається до навчальних планів вищого навчального закладу за місцем основного (базового) навчання, як окрема навчальна дисципліна.

Військова підготовка громадян України за програмою підготовки офіцерів запасу здійснюється за різними військовообліковими спеціальностями. Чисельність громадян для навчання та їх розподіл між військово-обліковими спеціальностями щорічно визначається наказом Міністра оборони України [7].

Військова підготовка проводиться у межах обсягу надання відповідної освітньої послуги, що визначається Генеральним Штабом Збройних Сил України:

1. За державним замовленням за рахунок коштів державного бюджету, передбачених на утримання 3бройних Сил України та інших військових формувань.

2. Для надання фізичним особам платних послуг у галузі вищої освіти, пов'язаних 3 військовою підготовкою, для забезпечення реалізації права таких осіб на рівні можливості у виборі професії шляхом здобуття додаткових знань, умінь і навичок, необхідних для належного виконання військового обов'язку в запасі у мирний час, обов'язків військової служби у воєнний час та для майбутньої професійної діяльності [8].

Розподіл ВОС та визначення обсягів підготовки за ними здійснюється
Міністерством оборони України за поданням Генерального штабу Збройних Сил України за погодженням з Міністерством освіти та науки України.

Для проведення військової підготовки у військовому навчальному підрозділі ЗВО між Міністерством оборони України та 3ВО, на базі військового навчального підрозділу якого проводиться військова підготовка, укладається договір про проведення такої підготовки 3 визначенням умов ії фінансування. У разі коли 3ВО, на базі військового навчального підрозділу якого проводиться військова підготовка, підпорядкований центральному органу виконавчої влади, який здійснює керівництво військовим формуванням, правоохоронним органом спеціального призначення відповідний договір укладається між таким центральним органом виконавчої влади та зазначеним 3ВО [8].

Для проведення військової підготовки студентів, які навчаються у 3ВО, що не має військового навчального підрозділу, укладається договір про проведення такої підготовки та умови їі фінансування між зазначеним ЗВО та закладом вищої освіти, на базі військового навчального підрозділу якого проводиться військова підготовка чи вищим військовим навчальним закладом.

$\mathrm{Ha}$ цей час військова підготовка складається:

3 теоретичного і практичного курсу військової підготовки;

комплексних практичних занять 3 вивчення курсу первинної військовопрофесійної підготовки (після 1-го року навчання);

навчального збору (після 2-го року навчання - завершальний етап навчання, що включає випускний екзамен і складання Військової присяги).

Зміст комплексних практичних занять складає тактична, розвідувальна, інженерна, психологічна підготовка, військова топографія, підготовка зі зв'язку, радіаційний, хімічний, біологічний захист, військовомедична, вогнева, стройова підготовка, статути Збройних Сил України та їх практичне 
застосування.

Комплексні практичні заняття в першу чергу спрямовуються на вивчення громадянами України досвіду бойових дій підрозділів та військових частин Збройних Сил України набутого під час виконання бойових завдань в зоні проведення АТО та оОс, з метою формування у них високих морально-психологічних,

військовопрофесійних та лідерських якостей для подальшого виконання військового обов'язку за призначенням.

Проведення навчального збору $\epsilon$ завершальним етапом військової підготовки громадян.

На навчальному зборі вдосконалюються командирські та методичні навички громадян, отримані ними під час засвоєння програми військової підготовки, виконуються вправи зі стрільб, водіння військової (бойової) техніки та вирішуються інші практичні завдання. Завершальним етапом навчального збору є здача випускного іспиту та складання громадянами України Військової присяги [8].

Система підготовки офіцерів запасу повинна забезпечувати 3С України кваліфікованими військовими фахівцями всіх рівнів і ланок управління, а також:

реалізовувати кваліфіковану підготовку офіцерських кадрів;

підвищувати кваліфікації офіцерського складу різних рівнів і ланок управління;

сприяти створенню інтелектуальних, духовних і матеріальних цінностей в інтересах національної безпеки та оборони України;

сприяти зміцненню бойової та мобілізаційної готовності 3С України.

Окрім того, до практичних результатів належать:

творче розв'язання проблеми оптимальної інтеграції військової та цивільної освіти;

розроблення ефективної методики формування державного замовлення на підготовку військових фахівців;

обґрунтування методики формування змісту підготовки військових фахівців усіх рівнів і ланок управління; розроблення документів і методик зі стандартизації та інформатизації військової освіти;

обґрунтування технології ефективного управління СВО та якістю підготовки військових фахівців;

реалізація конкретних практичних підходів щодо налагодження міжнародного співробітництва у сфері військової освіти.

Останнім часом в Україні стосовно системи підготовки офіцерів запасу (СПОЗ) існують дві протилежні думки. Деякі фахівці та вчені вважають, що необхідність у підготовці офіцерів запасу із числа студентів відпала, так як події на Сході України показали низьку ефективність та якість підготовки цієї категорії громадян, тим більше, що на особливий період їх підготовлено достатньо. Якщо припустити, що це дійсно так, то постає наступна проблема: чому в своїй більшості вони не готові до виконання своїх функціональних обов'язків за призначенням? Однією із причин цьому, мабуть, є те, що в існуючій СПОЗ не працюють механізми перепідготовки (підвищення кваліфікації) офіцерів запасу. Цю проблему пропонується розв'язати шляхом поновлення практики проведення періодичних навчальних зборів для удосконалення знань та практичних навичок офіцерів запасу. Зазначене свідчить про доцільність зосередження підготовки офіцерів запасу в регіональних навчальнометодичних Центрах, які необхідно створити при провідних ВВНЗ України.

Прихильники протилежної думки підтримують подальше утворення кафедр військової підготовки у ЗВО. Це безумовно приведе, на нашу думку, до негативних наслідків і, в тому числі, до зниження загального рівня (якості) підготовки офіцерів запасу. Тому додатково утворювати кафедри військової підготовки у регіонах, де $\epsilon$ ВВНЗ, недоцільно.

Багато проблем, на цей час, пов'язані також із застосуванням у підготовці майбутніх фахівців сучасних інформаційних технологій та засобів імітаційного моделювання, і які, на жаль, поки що не знайшли свого вирішення (крім знов ж таки ВВНЗ) ні у теоретичному, ні 
у практичному аспектах. А набутий при цьому досвід свідчить про наявність у сучасній організації ВНП ЗВО низки протиріч:

між традиційними формами методичного забезпечення навчального процесу та потребою в інноваційних формах подання інформації з урахуванням сучасних тенденцій збройної боротьби;

між процесом інформатизації військової освіти та відсутністю загального підходу щодо розробки, створення та забезпечення засобами навчання, які органічно поєднують сучасні педагогічні та інформаційні технології.

Зрозуміло, що суттєво впливають на ці процеси і складне фінансово-економічне становище в державі і недостатня кваліфікація частини науково-педагогічних працівників.

Зазначені протиріччя визначають основні проблемні питання, що притаманні організації освітнього процесу в сучасній системі підготовки офіцерів запасу, а саме:

обґрунтування методика застосування сучасних освітніх технологій, що синтезують педагогічні інновації, інформаційні, інформаційно-комунікаційні технології та засоби імітаційного моделювання 3 урахуванням сучасних поглядів щодо збройної боротьби;

інтеграція традиційних педагогічних технологій з комп'ютерними технологіями в освіті;

модернізація імітаційних комп'ютерних моделей навчання та застосування їх у навчальному процесі вищого військового навчального закладу.

Основним шляхом розв'язання даних проблем, що пропонується більшістю науковців, $€$ впровадження у освітню діяльність інноваційних технологій (інноваційного навчання) та всебічна технологізація освітнього процесу.

Практика та передовий педагогічний досвід свідчать, що форма військової підготовки “методом військового дня" неоптимальна і значно поступається такій формі, як навчальний збір. Достатньо нагадати, що для збереження у пам'яті людини отриманої інформації необхідно якнайшвидше ії повторити. У іншому випадку через дев'ять годин залишається лише 30 \% отриманої інформації і далі цей показник зменшується за експонентним законом. Крім того, впровадження по семестрових навчальних зборів, як основного методу військової підготовки, спрощує систему планування навчальних занять та взаємодію із цивільними ЗВО.

Певні проблеми у функціонуванні СПОЗ пов'язані також 3 якістю кваліфікаційних характеристик, навчальних планів та програм військової підготовки. На цей час вони різні за структурою і змістом у різних ВНП ЗВО та ВВНЗ для однієї військово-облікової спеціальності. Тому необхідно провести уніфікацію кваліфікаційних характеристик, навчальних планів та програм військової підготовки в усіх ВНП ВНЗ та ВВН3, тобто привести розробку цих документів у відповідність з вимогами керівних документів. Зазначене також додатково свідчить про доцільність зосередження підготовки офіцерів запасу в регіональних навчально-методичних Центрах, які необхідно створити при провідних ВВНЗ України [9].

Якісна підготовка офіцерів запасу неможлива без відповідної навчальноматеріальної бази, у першу чергу без сучасного озброєння та військової техніки. На сьогоднішній день у більшості ВНП ЗВО майже 90\% зразків ОВТ такі, що були виготовлені задовго до 1990 року i відносяться до IV та V категорій (IV категорія зразки, що потребують капітального ремонту і можуть використовуватись в якості навчальних макетів; V категорія - зразки, що ремонту не підлягають, а їхнє відновлення економічно недоцільне) [4].

Відсутність нових зразків ОВТ практично у всіх ВНП (мабуть, крім навчальних підрозділів ВВН3 ЗСУ), особливо засобів розвідки і зв'язку, не дозволяє здійснити підготовку офіцерів запасу як фахівців, які у повній мірі здатні виконувати посадові обов'язки за відповідними військово-обліковими спеціальностями. Крім того, постачання нових та перспективних зразків ОВТ до ВНП ЗВО неможливе без державного замовлення, 
що також свідчить на користь проведення оптимізації структури СПОЗ та створення потужних навчально-методичних регіональних Центрів підготовки офіцерів запасу при провідних ВВНЗ України де проходить фахова підготовка офіцерів і $\epsilon$ можливість при підготовці офіцерів запасу використовувати відповідну навчальноматеріальну базу.

Ми цілком підтримуємо висновки наукових розвідок С. Морозова, який акцентує, що "професійна підготовка офіцерів запасу буде ефективною в разі створення на військових кафедрах вищих навчальних закладів таких організаційнопедагогічних умов:

зміст військово-професійної освіти офіцерів запасу максимально наближений до застосування ними результатів навчання у майбутній професійній діяльності, адекватно відображає сучасні тенденції розвитку та відповідає основним напрямам модернізації військової підготовки на основі інтенсифікації методів навчання, упровадження сучасних освітніх технологій, зокрема інформаційних;

здійснюється врахування загальних закономірностей формування особистості та індивідуальних особливостей майбутніх офіцерів, розвитку в кожному з них індивідуальних здібностей, інтересів і схильностей;

досягнуто готовності викладачів військових кафедр у науково-методичному, теоретичному і практичному спрямуванні до реалізації вищезазначених вимог" [10].

\section{Висновки}

Таким чином, розглянуті вище проблемні питання функціонування системи підготовки офіцерів запасу для $3 \mathrm{C}$ України підтверджують необхідність ії удосконалення. Проведений аналіз проблеми підготовки офіцерів запасу однозначно показав необхідність всебічного і глибокого дослідження мети, завдань і в

цілому порядку та ефективності функціонування системи підготовки офіцерів запасу на цей час.

Перспективами подальших наукових досліджень у даному напрямі може бути обґрунтування, доцільності мати у Державі таку організаційну форму підготовки офіцера.

\section{Список використаних джерел}

1. Жолудь О. В Існуючі показники співвідношень категорій особового Складу зС України та оптимізація їх у відповідності до стандартів країн НАТО. Наукові праці: наук. журн. / Чорном. нац. ун-т ім. Петра Могили; Миколаїв, 2017. Т. 298. Вип. 286. $124 \mathrm{c}$.

2. Баришніков, В. В., Нейми, О. К. Шляхи вдосконалення підготовки офіцерів запасу в Україні. Системи обробки інформації. 2015. вип. 8 (133), С. 158-161.

3. Черних, Ю. Черних, О. Черних Аналіз деяких проблем підготовки офіцерів запасу у військовому інституті: підсумки соціологічного опитування. Вісник Київського національного університету ім. Тараса Шевченка. Військово-спеціальні науки. 2(42). 2019.

4. Медвідь, Ю. І. Формування готовності майбутніх офіцерів запасу до службовобойової діяльності в процесі професійної підготовки: дис. канд. пед. наук: 13.00.04 / Медвідь Юлія Іванівна; Глухів. нац. пед. унт ім. Олександра Довженка. - Глухів, 2019. - 240 c.

5. Про заходи щодо підвищення обороноздатності держави: Указ Президента України від 01.05.2014 року №447/2014. URL: https://www.president.gov.ua/documents/447 2014-17155

6. Про затвердження Інструкції про організацію військової підготовки громадян України за програмою підготовки офіцерів запасу (із змінами внесеними наказом Міністерства освіти і науки України та Міністерства оборони України від 18.06.19 № 316/833): наказ Міністерства освіти і науки України та 
Міністерства оборони України від 15.12.15 № 719/1289.

7. Про затвердження Інструкції про організацію підготовки офіцерів запасу 3 числа студентів вищих навчальних закладів: Наказ Міністерства оборони України, Міністерства освіти і науки України № 531/857 від 11.11.2004 p.

8. Бойко О. Прогресивні концепції і технології навчання як основа підготовки офіцерських кадрів для Сухопутних військ Збройних Сил України. Вісник Львів УН-ТУ, Серія педагогічна. 2007. Вип. 22, С. 106-113.

9 Толок І. В. Виступ на нараді з питань підготовки офіцерів запасу 16 вересня $2014 \mathrm{p}$.

10. Морозов С. М. Педагогічні засади професійної підготовки офіцерів запасу у вищих навчальних закладах. Збірник наукових праць Національної академії Державної прикордонної служби України. Серія: Педагогічні та психологічні науки. 2013. № 1. C. 127-137.

\title{
Анализ проблем профессиональной подготовки граждан Украины по программе подготовки офицеров запаса
}

\author{
Максим Касьяненко * А \\ "Corresponding author: к.в.н., заместитель директора департамента, e-mail: zdd_dvon@mil.gov.ua, ORCID: 0000-0002-3749-4441 \\ А Департамента военного образования и науки Министерства обороны Украины, пр-кт Воздухофлотский, 28, г. Киев, 03049, Украина
}

\begin{abstract}
Аннотация
Статья посвящена анализу состояния подготовки будущих офицеров запаса. События на Востоке Украины раскрыли целый ряд проблем в системе подготовки офицеров запаса. По результатам анализа научных работ установлено, что в процессе военной подготовки граждан Украины по программе подготовки офицеров запаса не учитываются такие факторы, как изменение образа комплектования воинских формирований, внедрение стандартов НАТО в военной сфере, опыт боевых действий на Востоке Украины. В статье определены особенности и предложены пути совершенствования системы подготовки офицеров запаса.

Цель статьи является анализ основных проблемы профессиональной подготовки граждан Украины по программе подготовки офицеров запаса и рассмотреть пути дальнейшего совершенствования системы подготовки офицеров запаса, как одного из видов воинского долга.
\end{abstract}

Ключевые слова: военная подготовка, офицеры запаса, военно-профессиональная деятельность, система профессиональной подготовки, профессиональная готовность.

\section{Analysis of professional training problems for citizens of Ukraine according to the training of reserve officers' program}

\author{
Maxim Kasianenko * A \\ "Corresponding author: Ph.D., Deputy Director of the Department, e-mail: zdd_dvon@mil.gov.ua, ORCID: 0000-0002-3749-4441 \\ ${ }^{A}$ Department of Military Education and Science of the Ministry of Defence of Ukraine, 28, Povitroflotskyi Ave, Kyiv, 03049, Ukraine
}

\begin{abstract}
The article is devoted to the analysis of the state of future reserve officers training. The events in eastern Ukraine have revealed a number of problems in the reserve officer training system. According to the results of the analysis of scientific works, the military training of Ukrainian citizens in the training program of reserve officers does not take into account such factors as changing the method of manning military formations, implementation of NATO standards in the military sphere, combat experience in eastern Ukraine. The article identifies the features and
\end{abstract}


suggests ways to improve the training system of reserve officers.

The purpose of the article is to analyze the main problems of professional training of citizens of Ukraine in the training program of reserve officers and to consider ways to further improve the system of reserve officers training as a type of military service.

Keywords: military training, reserve officers, military-professional activity, system of professional training, professional readiness.

\section{References}

1. Zholud O. V Isnuiuchi pokaznyky spivvidnoshen katehorii osobovoho Skladu ZS Ukrainy ta optymizatsiia yikh u vidpovidnosti do standartiv krain NATO. Naukovi pratsi: nauk. zhurn. / Chornom. nats. un-t im. Petra Mohyly; Mykolaiv, 2017. T. 298. Vyp. 286. 124 s. [in Ukraine]

2. Baryshnikov, V. V., Neimy, O. K. Shliakhy vdoskonalennia pidhotovky ofitseriv zapasu v Ukraini. Systemy obrobky informatsii. 2015. vyp. 8 (133), S. 158-161. [in Ukraine]

3. Chernykh, Yu. Chernykh, O. Chernykh Analiz deiakykh problem pidhotovky ofitseriv zapasu u viiskovomu instytuti: pidsumky sotsiolohichnoho opytuvannia. Visnyk Kyivskoho natsionalnoho universytetu im. Tarasa Shevchenka. Viiskovo-spetsialni nauky. 2(42). 2019. [in Ukraine]

4. Medvid, Yu. I. Formuvannia hotovnosti maibutnikh ofitseriv zapasu do sluzhbovoboiovoi diialnosti $v$ protsesi profesiinoi pidhotovky: dys. kand. ped. nauk: 13.00.04 / Medvid Yuliia Ivanivna; Hlukhiv. nats. ped. un-t im. Oleksandra Dovzhenka. Hlukhiv, 2019. 240 s. [in Ukraine]

5. Pro zakhody shchodo pidvyshchennia oborono-zdatnosti derzhavy: Ukaz Prezydenta Ukrainy vid 01.05.2014 roku №447/2014. URL: https://www.president.gov.ua/documents/4 472014-17155. [in Ukraine]
6. Pro zatverdzhennia Instruktsii pro orhanizatsiiu viiskovoi pidhotovky hromadian Ukrainy za prohramoiu pidhotovky ofitseriv zapasu (iz zminamy vnesenymy nakazom Ministerstva osvity i nauky Ukrainy ta Ministerstva oborony Ukrainy vid 18.06.19 № 316/833): nakaz Ministerstva osvity i nauky Ukrainy ta Ministerstva oborony Ukrainy vid 15.12.15 № 719/1289. [in Ukraine]

7. Pro zatverdzhennia Instruktsii pro orhanizatsiiu pidhotovky ofitseriv zapasu z chysla studentiv vyshchykh navchalnykh zakladiv: Nakaz Ministerstva oborony Ukrainy, Ministerstva osvity i nauky Ukrainy № 531/857 vid 11.11.2004 r. [in Ukraine]

8. Boiko O. Prohresyvni kontseptsii i tekhnolohii navchannia yak osnova pidhotovky ofitserskykh kadriv dlia Sukhoputnykh viisk Zbroinykh Syl Ukrainy. Visnyk Lviv UN-TU, Seriia pedahohichna. 2007. Vyp. 22, S. 106113. [in Ukraine]

9. Tolok I. V. Vystup na naradi z pytan pidhotovky ofitseriv zapasu 16 veresnia 2014 r. [in Ukraine]

10. Morozov S. M. Pedahohichni zasady profesiinoi pidhotovky ofitseriv zapasu $u$ vyshchykh navchalnykh zakladakh. Zbirnyk naukovykh prats Natsionalnoi akademii Derzhavnoi prykordonnoi sluzhby Ukrainy. Seriia: Pedahohichni ta psykholohichni nauky. 2013. № 1. S. 127-137. [in Ukraine] 